Annals of Warsaw University of Life Sciences - SGGW

Land Reclamation No 40, 2008: 45-54

(Ann. Warsaw Univ. of Life Sci. - SGGW, Land Reclam. 40, 2008)

\title{
The flood extent in the lower Biebrza basin calculated by the 1D flow model for different land use scenarios
}

\author{
SYLWIA SZPORAK, DOROTA MIROSŁAW-ŚWIĄTEK, \\ JAROSŁAW CHORMAŃSKI \\ Department, of Hydraulic Engineering and Environmental Restoration, Warsaw University of Life \\ Sciences
}

\begin{abstract}
The flood extent in the lower Biebrza basin calculated by the $1 D$ flow model for different land use scenarios. An application of an steady 1D flow model for determination of a flood extent in the natural river valley is discussed in this paper. The Pasche method was used to calculate the total Darcy-Weisbach friction factor for each cross section according to the type of vegetation and flow interaction between the main channel and vegetated areas. In this approach friction caused by interaction between the main channel and vegetated areas are taken into account. The model was applied to the Biebrza Valley, fairly undisturbed river-marginal peatland, located in the north-east of Poland. Actual land use carried out in the National Park was analyzed to determine the influence of changes in the vegetation structure on the flood extent in the river valley. The obtained results show variation of a flooded area in relation to the vegetation of the floodplain.
\end{abstract}

Key words: 1D flow model, absolute roughness.

\section{INTRODUCTION}

The aim of this work was determining changes of water conditions on the floodplain as a result of a different vegetation management scenarios leading to different vegetation successions. These changes of water conditions were described by a flood extent on floodplains The steady river flow model, which takes into water level calculation spatial distributed friction factors according to type of floodplain vegetation and flow interaction between main channel and vegetated areas, was used with the GIS techniques as a tool for a flood extent evaluation. In this approach, roughness height coefficients and hydraulic characteristic of vegetation covering floodplains are very significant. Therefore methods determination of these hydraulic characteristics of low and high vegetation in Lower Biebrza Basin was particularly described.

\section{MATERIALS AND METHODS}

Hydraulic calculations of the riverbed capacity require methods which include natural vegetation structure of the river waterside zones and the floodplain. The values of the resistance coefficients of the floodplain vegetation still belong to rareness. Presently the most often used are roughness coefficients for Manning's equation, but the choice of the sufficient one among the tabular values is subjective. Another method is determination of plant characteristics elaborated by Rouvč (1987). The division on high, medium and low vegetation (proposed by Bretschneider and Schulz 1985) is used in such calculations. 
High vegetation is considered here as higher than water flow depth (trees and shrubs) and in small degree go under hydrodynamic water pressure, medium vegetation as approximately equal to water depth (mostly shrubs) and low vegetation which refers mostly to sedge and grass communities (Fig. 1). them in the direction of the water flow and transversal to it. Named parameters are determined on the basis of field measurements in the area of the water flow. The methodology of plant characteristics determination proposed by German engineers was applied in this study for high and medium vegetation in 13 cross

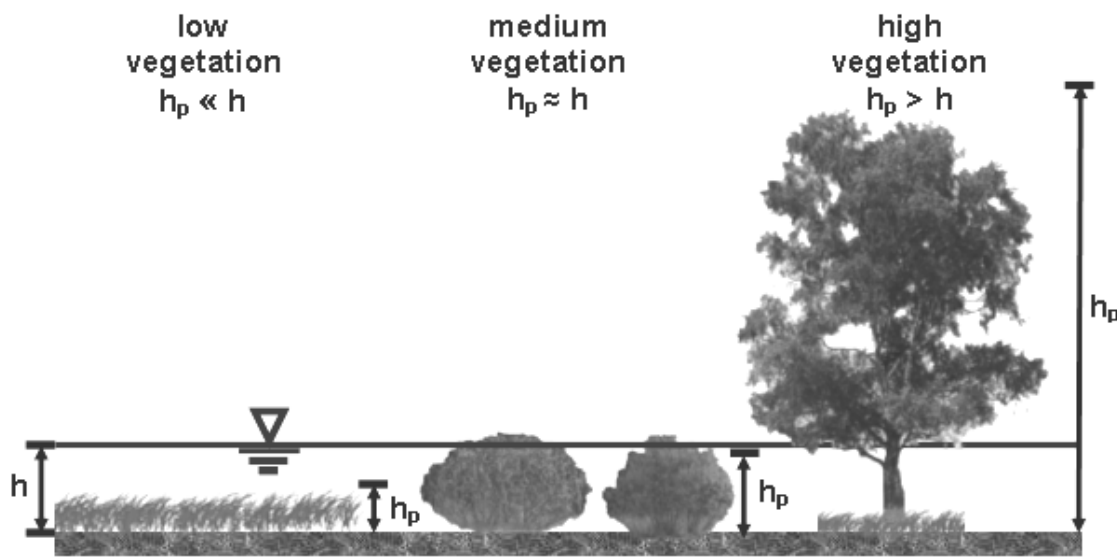

FIGURE 1. Vegetation classification proposed by Bretschneider and Schulz (1985)

Established criterion is ambiguous and in fact the same vegetation can be ranked into different types in view of the natural water levels variability.

\section{High and medium vegetation}

The basis of hydraulic calculations of riverbed capacity including its natural vegetation structure is assumption that water flow resistances are the same as resistances which occur when water overflow regularly distributed vegetation with averaged geometric parameters (DVWK 1991; Kubrak and Nachlik 2003).

Parameters which describe vegetation of the floodplain and are used in calculations are an average tree diameter or shrub branches and distances between sections (Fig. 7) established in the Lower Biebrza Basin (DVWK 1991).

\section{Low vegetation}

Resistance coefficients $\lambda$ of low vegetation are calculated from Colebrook-White'a equation on the basis of relative roughness value $\mathrm{k}_{\mathrm{s}}$ determined for given type of vegetation (Indlekofer 1981):

$$
\frac{1}{\sqrt{\lambda}}=-2.0 \log \left(\frac{2.51}{\operatorname{Re} \sqrt{\lambda}}+\frac{k_{s} / R}{14.84}\right)
$$

where, $R e$ is a Reynold's number, $R$ - hydraulic radius [m], $\lambda$ - friction factor not overgrown part of a channel [-], $k_{s}$ - roughness bed of a channel [m].

The roughness height for vegetation in the Lower Biebrza Basin is determined 


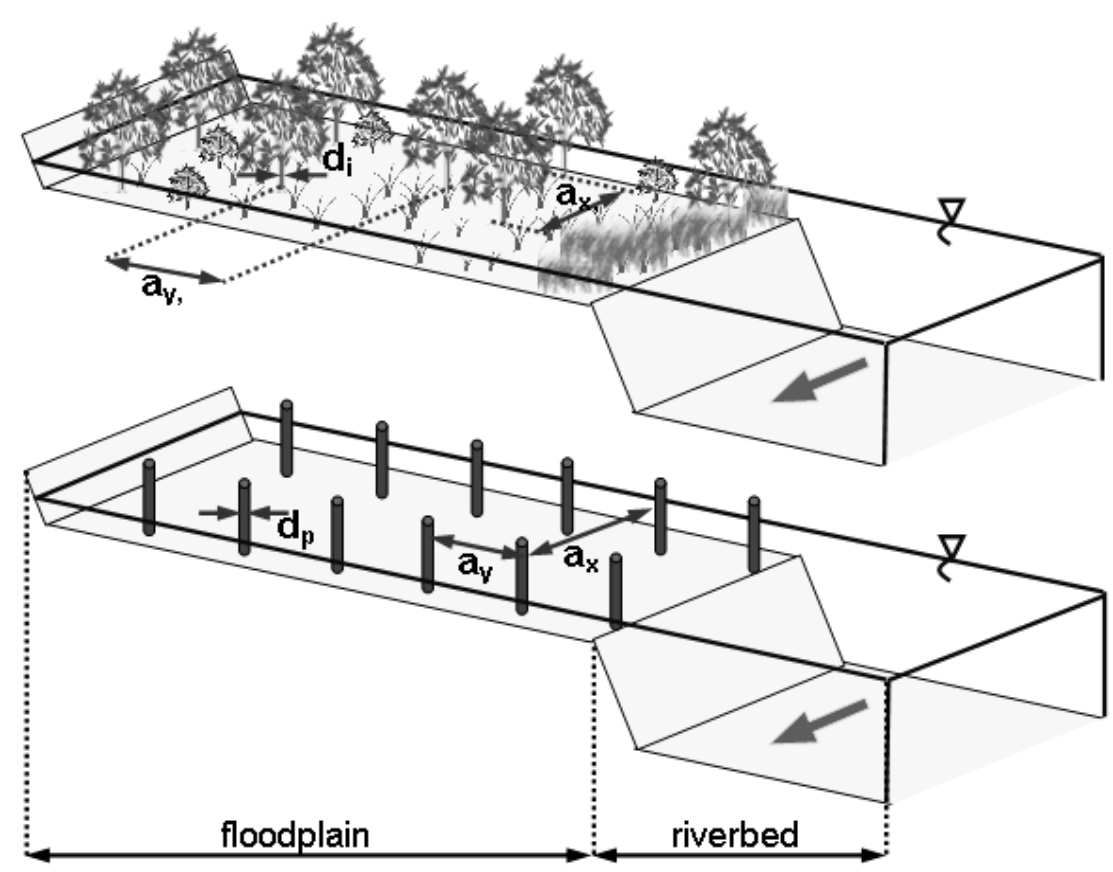

FIGURE 2. The high vegetation geometric characteristics

on the basis of values given by Ritterbach (1991) for the Wüpper River Valley in Germany and field measurements of particular vegetation type's height. On the basis of determined values (Tab. 1) different scenarios of land use were prepared.

In this paper the plant characteristics determination method is presented for the wetland vegetation in the Lower Biebrza Basin. Obtained results were used for 1D modelling in order to evaluate the influence of a different land use on the flood extent.

Plant characteristics were determined here for four different land use scenarios in order to designate their influence on a flood extent in the Lower Biebrza Basin. The land use changes in the model boil down to changes in absolute roughness coefficient values.
The first one (scenario 1) presents actual state with agricultural and protection activities carried out nowadays in the National Park (Fig. 3).

The second (scenario 2) takes under consideration situation when wet meadows (Molinion and Calthion), tall sedge plant communities (Magnocaricion) and pastures are embraced by extensive agriculture. In this situation the whole area covered by these plant communities is taken under account (Fig. 4).

In the Biebrza river valley, Magnocaricion covers areas which are reinforced mostly by rich surface water from the river, but also places with shallow stagnant water. In this scenario meadows are mainly mowed for cattle bedding and rarely used for hay, but play significant role in wetland ecosystems as natural filters for surface water and 
TABLE 1 . The roughness height values adopted for different vegetation types under different land use in the Lower Biebrza Basin

\begin{tabular}{|l|c|c|c|}
\hline \multirow{2}{*}{ Vegetation type } & \multicolumn{3}{|c|}{ Absolute roughness $k_{s}[\mathrm{~m}]$} \\
\cline { 2 - 4 } & \multicolumn{2}{|c|}{ during vegetation period } & beyond vegetation period \\
\cline { 2 - 4 } & no activity & $\begin{array}{c}\text { active } \\
\text { protectionn }\end{array}$ & no activity \\
\hline Grasses & 0.5 & 0.1 & 0.3 \\
\hline $\begin{array}{l}\text { Grasses and loose tussock sedges } \\
\text { mosaic }\end{array}$ & 0.6 & 0.1 & 0.4 \\
\hline Loose tussock sedges & 0.6 & 0.15 & 0.4 \\
\hline $\begin{array}{l}\text { Loose and compact tussock } \\
\text { sedges mosaic }\end{array}$ & $0.6-1.2$ & 0.2 & 0.5 \\
\hline Compact tussock sedges & 1.2 & 1.2 & 0.5 \\
\hline Reed & 1.2 & 0.2 & 1.2 \\
\hline Glycerietum maximae & $0.6-1.2$ & 0.2 & 0.4 \\
\hline Willow shrubs & 0.4 & 0.4 & 0.4 \\
\hline Swampy birch forest & $0.8-1.6$ & - & 0.8 \\
\hline Black alder forest & $0.8-1.6$ & - & 0.8 \\
\hline Deciduous or coniferous tall forest & 0.4 & - & 0.3 \\
\hline
\end{tabular}

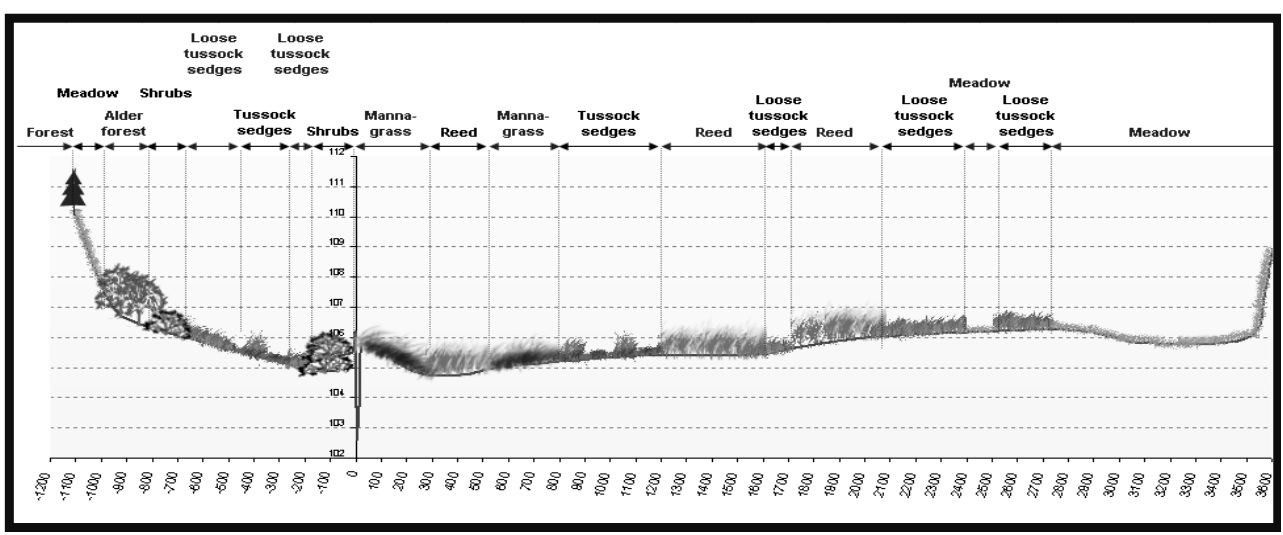

FIGURE 3. Example: Scenario 1 - actual state (bd3 cross section)

water retention zones. The natural value of wet meadows depends on frequency, terms and mowing methods. Single mowed meadows (Molinion) belong to one of the most valuable phitocenosis associated with river valleys (Kotowski and Piórkowski 2006) as they are rich in species (often very rare), and every year, late mowing determine their existence. Calthion meadows which are double or three time mowed help to protect the surface soil layer from excessive dryness and prevent or slow down the time of organic soil mineralization processes. Pastures in Biebrza valley are situated mostly in zones near the river. The best 


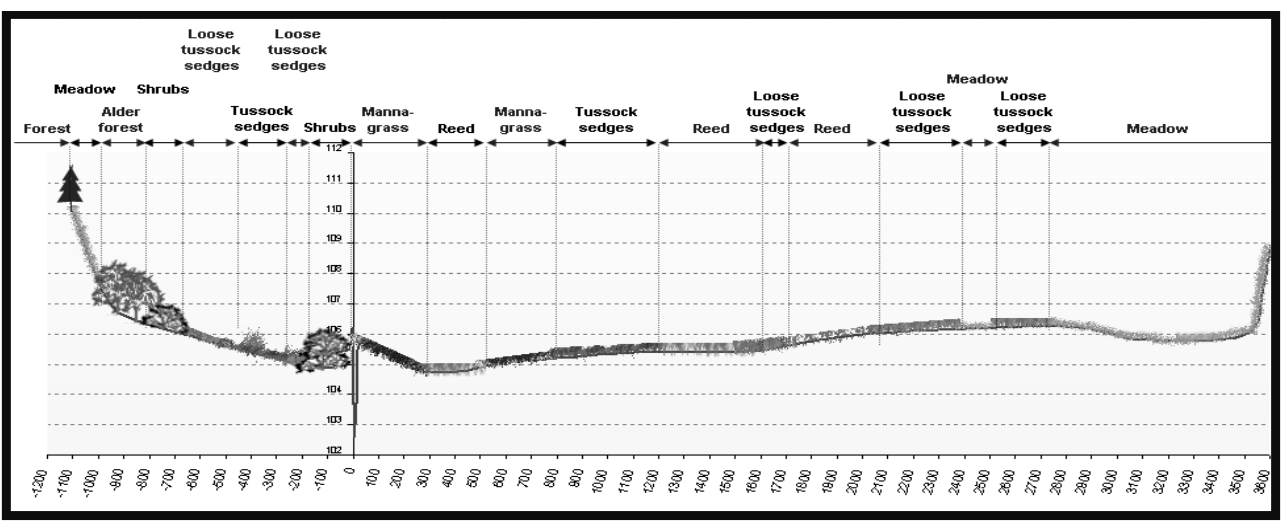

FIGURE 4. Example: Scenario 2 - reed, meadow, manna grass and sedge mowing (bd3 cross section)

extensive agriculture method here is shrubs and birch forest upon nongrazing with the small cattle mount. forest ecosystems of peatlands without This scenario includes also Phragmition any extensive agricultural practices and Filipendulion plant communities (simulation of the future) (Fig. 6). in agricultural use. The overgrowing process in many cases seem to be the natural succession, but taking under consideration the protection of the National Park the overgrowing processes are an unprofitable occurrence which decreases biodiversity, that's why the third scenario (scenario 3) takes also into account willow shrubs and birch trees cutting (Fig. 5).

The fourth scenario (scenario 4) allows the natural succession of willow

\section{The flood extent calculation in the lower Biebrza Basin}

The flood extent calculation was performed in this paper based on steady river flow. The water level profile in steady gradually-varied flow was calculated using the standard step method. This method is characterized by dividing the river with compound cross sections into short reaches and

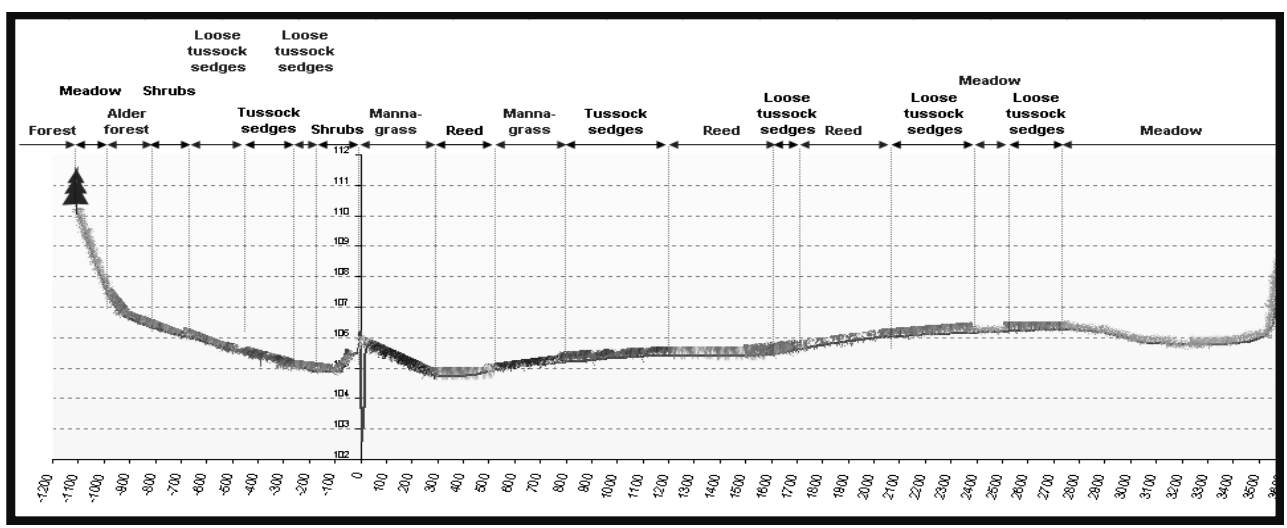

FIGURE 5. Example: Scenerio 3 - willow shrubs and trees cutting (bd3 cross section) 


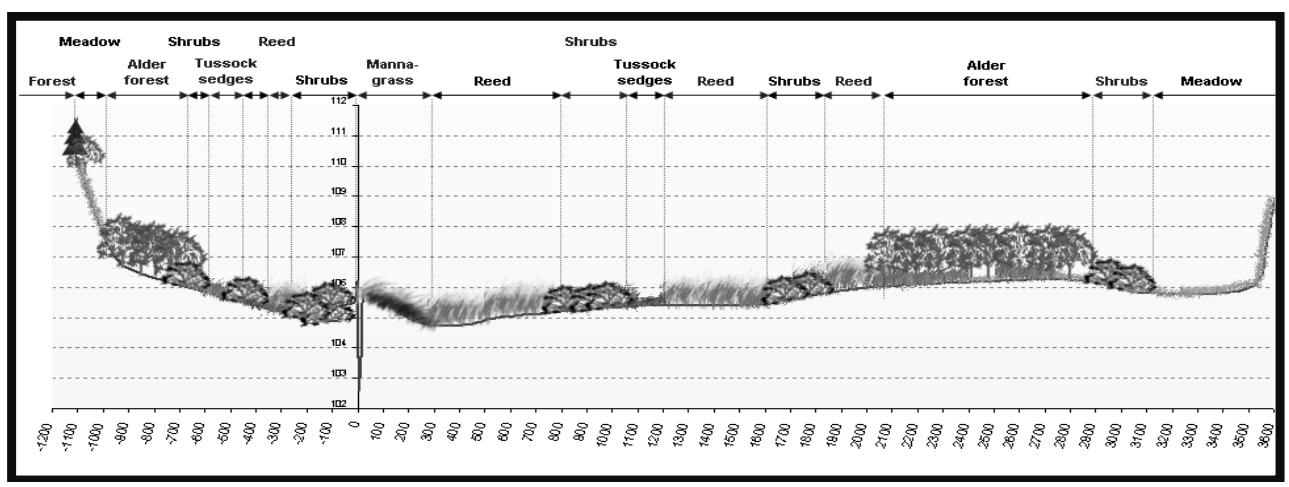

FIGURE 6. Example: Scenerio 4 - natural succession (bd3 cross section)

then carrying the computation gradually from one end of the reach to the other. Problem is formulated as follows:

For a given discharge, there is the river stage $\mathrm{H}_{2}$ known at one section downstream and it is required to calculate the stage $\mathrm{H}_{1}$ at the adjacent section upstream. A plan of the waterway is available at the both sections, from which values of cross section area, wetted perimeter, mean velocity, perimeter of vegetation, etc., can be determined for a given stage (Świątek et al. 2006). The discharge of the steady flow in the river was expressed as the product of the velocity and the water area. The mean velocity calculation was made using the Darcy-Weisbach formula. Velocities, friction factors and the components of discharge in the main channel and on the floodplains as well, were calculated according to the type of vegetation using momentum transfer between the main channel and the floodplains (Pasche 1984).

The cross-sections, in the number of 13 , were established at the distance of 2-6 km from each other along the river in order to describe the geometry of the river channel and the valley (Fig. 7).
The river bed elevations were measured using manual sounding. The floodplain morphology was represented by the Digital Elevation Model (DEM). The DEM of the Lower Basin was elaborated using ArcGIS by interpolation based upon the ANUDEM procedure (Hutchinson 1996) designed specifically for creation of the hydrologically correct DEM. The main data source was a set of the digital contour lines taken from topographic maps of 1:25000. Additionally, the floodplain elevation was measured directly in the several cross-sections. The DEM was created with cell resolution of 25 meters and next, verified by surveying (RMS $=0.35$ m) (Chormański 2003).

In the computation, the discharge at the upstream cross-section was used as the upper boundary condition, and the water level at the downstream as the lower boundary condition. Since the average distancebetweenmeasured cross-sections was about $3.4 \mathrm{~km}$ the interpolated crosssections were added with a space step of $0.5 \mathrm{~km}$. The model was successfully verified with help of processed Landsat satellite image and field measurements (Świątek et al. 2006). The water level 


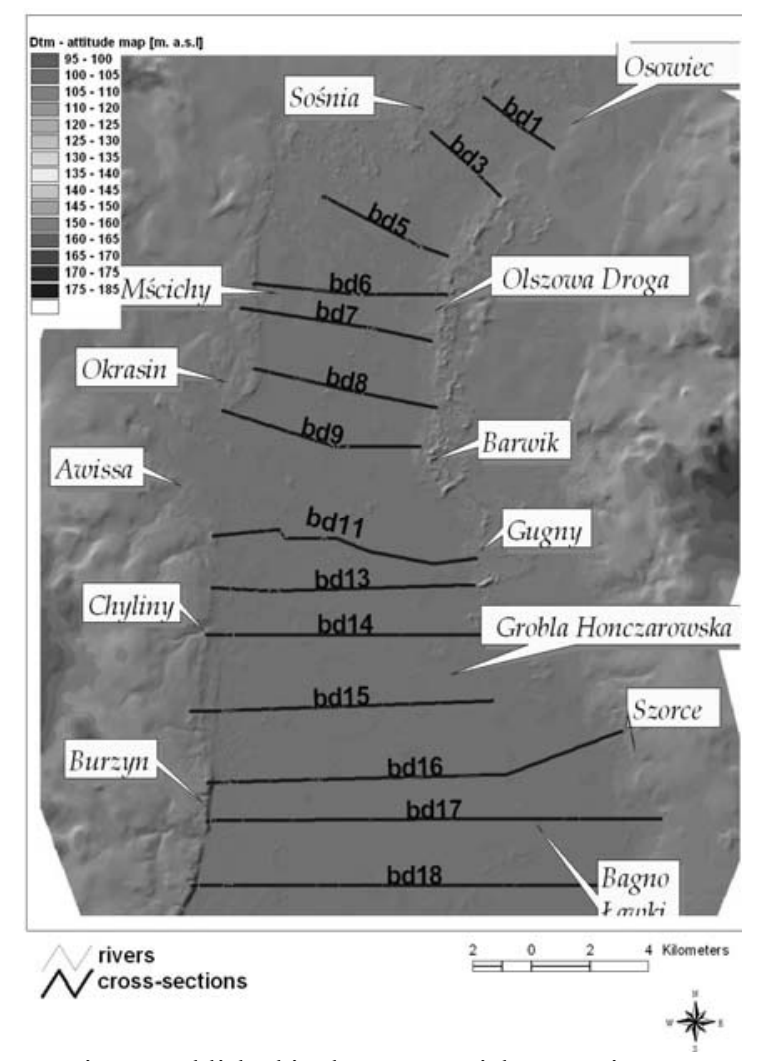

FIGURE 7. The cross sections established in the Lower Biebrza Basin

calculation was performed for the two following cases: absolute maximum $\left(\mathrm{MAX} Q=229.20 \mathrm{~m}^{3} / \mathrm{s}\right)$ and mean of maximum flows $\left(\mathrm{AVG} \mathrm{Q}=70.51 \mathrm{~m}^{3} / \mathrm{s}\right)$ of annual discharges for historical records 1965 to 1996.

The Digital Elevation Model was coupled with the hydraulic model for mapping the extent of the flood in the valley. The water stages were calculated by hydraulic model in cross-sections, then, interpolated into the elevation model of the surface water, and next mapped for the whole floodplain. The flood extent and average flood depth were determined by GIS analysis. This calculation was performed per each grid cell of the valley for the particular management scenarios respectively.

\section{RESULTS AND DISCCUSSION}

Table 2 and Figure 8 show results of performed calculation compared to the actual state (scenario 1). Both management activities, grass mowing (scenario 2) and shrubs and trees cutting (scenario 3) decreased the flood extent by about $8 \%$ for average flood and $10 \%$, for high flood. The average water depth decreased by $0.03 \mathrm{~m}$ and $0.05 \mathrm{~m}$ respectively. The difference between these two management scenarios is 


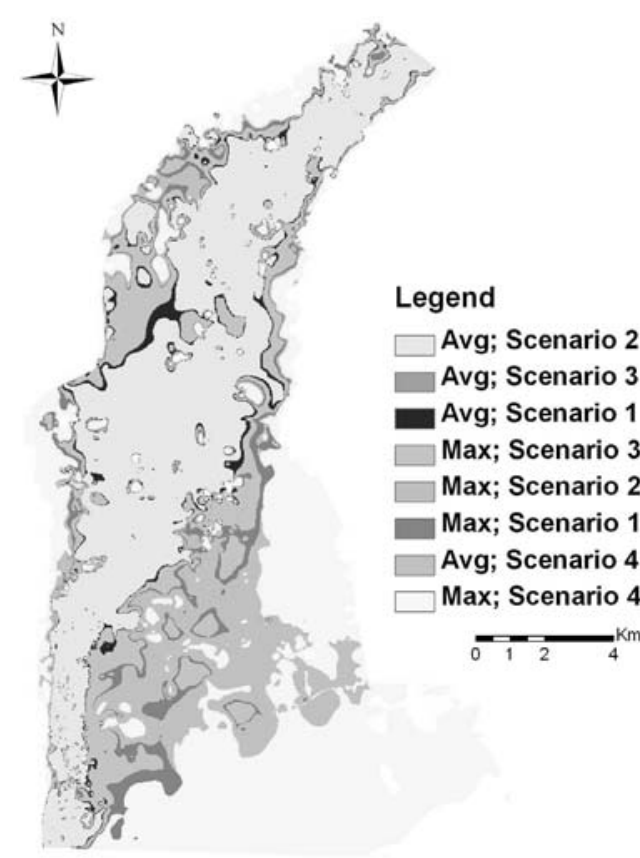

FIGURE 8 . The flooded area calculated for different management scenarios

not significant. Scenario 4 (natural succession of the willow shrubs), in which model simulate theoretical situation when there are no changes in environment - no management works - generates very significant differences in both flood extents and water depth. The flood extent increased by more than $100 \%$ in both average and high flood, while simulated water depth increased by $0.2 \mathrm{~m}$ for average and $0.80 \mathrm{~m}$ for high flood.

\section{CONCLUSIONS}

The hydraulic model coupled with GIS enables to consider proposed agricultural practices of management scenarios for
TABLE 2. Variation of the flooded area and the water depth on the floodplain for different land use scenarios $\left(\mathrm{MAX} \mathrm{Q}=229.20 \mathrm{~m}^{3} / \mathrm{s}, \mathrm{AVG} \mathrm{Q}=70.51\right.$ $\mathrm{m}^{3} / \mathrm{s}$ )

\begin{tabular}{|l|c|c|c|}
\hline Scenario & $\begin{array}{c}\text { Flooded } \\
\text { area } \\
{\left[\mathrm{km}^{2}\right]}\end{array}$ & $\begin{array}{c}\text { Average } \\
\text { depth } \\
{[\mathrm{m}]}\end{array}$ & $\begin{array}{c}\text { Flow } \\
\text { condition }\end{array}$ \\
\hline $1 \mathrm{MAX}$ & 93.29 & 0.65 & MAX \\
\hline $2 \mathrm{MAX}$ & 83.84 & 0.61 & MAX \\
\hline $3 \mathrm{MAX}$ & 83.21 & 0.60 & MAX \\
\hline $4 \mathrm{MAX}$ & 179.55 & 1.44 & MAX \\
\hline $1 \mathrm{AVG}$ & 61.35 & 0.49 & AVG \\
\hline $2 \mathrm{AVG}$ & 56.54 & 0.46 & AVG \\
\hline $3 \mathrm{AVG}$ & 56.27 & 0.45 & AVG \\
\hline $4 \mathrm{AVG}$ & 113.74 & 0.68 & AVG \\
\hline
\end{tabular}

flood extent and flood water depth in the valley. Insignificant differences in roughness coefficients as well as not enough representation of the floodplain by the DEM, with lack of measurement data, could cause that the flood differences between two management scenarios (grass mowing and shrubs cutting) were slight.

The results obtained show that the variation of the flood extent is related to the vegetation structure of the floodplain. The most significant difference in flood extent was in the scenario in which human management was absent and natural succession of vegetation was taking place. In this scenario birch forest and willow shrubs occurred over large areas of wetland resulting in a significant increase of flood extend and water depth. The ecological consequences i.e. changes of vegetation structure due to the modified flood characteristics should be solve in future development. 


\section{REFERENCES}

BRETSCHNEIDER H., SCHULZ A. 1985: Anwendung von Fließformeln bei naturnahem Gewässerausbau. DVWK - Schriften, Heft 72.

CHORMAŃSKI J. 2003: Metodyka wyznaczania zasięgu zalewu w Basenie Dolnym rzeki Biebrzy. [Methodology of flood extent determination in the Lower Biebrza Basin]. Ph.D. Thesis. Warsaw Agricultural University, 186.

DVWK - MERKBLÄTTER 220, 1991: Hydraulische Berechnung von Fließgewässern, DK 551.51/54 Fließgewässer, DK 532.543 Hydraulik, DVWK - Merkblätter 220/1991, Kommissionsvertrieb Verlag Paul Parey, Hamburg und Berlin.

HUTCHINSON M.F. 1996: A locally adaptive approach to the interpolation of digital elevation model. Third International Conference / Workshop on Integrating GIS and Environmental Modeling, Santa Fe, NM, January 21$-26,1996$. Santa Barbara, CA: National Center for Geographic Information and Analysis.

INDLEKOFER H. 1981: Überlagerung von Rauhigkeitseinflüssen beim Abfluß in offenen Gerinnen. Mitt. Institut für Wasserbau und Wasserwirtschaft, RWTH Aachen, Heft 37, 105-145.

KOTOWSKI W., PIÓRKOWSKI H. 2006: Woda w krajobrazie rolniczym. Woda, Środowisko, Obszary Wiejskie. [Water in agricultural landscape. Water, Environment, Countryside]. $\mathrm{Nr} 18$, Instytut Melioracji I Użytków Zielonych, Wydawnictwo IMUZ, Falenty.

KOZIOŁ A., KUBRAK J., CIEPIELOWSKI A. 2002: Hydrauliczny model przepustowości koryt rzecznych w warunkach występowania roślinności leśnej. [Hydraulic model of river flow capacity under forest condition]. Czasopismo Techniczne Inżynieria Środowiska, Zeszyt 4, Wydawnictwo Politechniki Krakowskiej.
KOZIOŁ A., 2003: Określenie geometrycznych parametrów roślinności wykorzystywanych $\mathrm{w}$ obliczeniach przepustowości terenów zalewowych.[Determination of plant characteristics used in calculations of flow capacity of the floodplain]. Gospodarka Wodna nr 8/2003.

KUBRAK J., NACHLIK E. (ed.), 2003: Hydrauliczne podstawy obliczania przepustowości koryt rzecznych. [Hydraulic basis of the river flow capacity determination]. Wydawnictwo SGGW, 317.

MATUSZKIEWICZ M. 2000: Mapa zbiorowisk roślinnych Biebrzańskiego Parku Narodowego. [Plant communties map for the Biebrza National Park]. Plan ochrony BPN. Krajowy Zarząd Parków Narodowych.

PASCHE E. 1984: Turbulenzmechanismen in naturnahen Fließgewässern und die Möglichkeit ihrer mathematischen Erfassung. Thesis presented for the degree of Doctor in Applied Sciences, RWTH, Aachen.

RITTERBACH E. 1991: Wechselwirkungen zwischen Auenökologie und Fließgewässerhydraulik und Möglichkeiten der integrierenden computergestützten Planung. Mitteilungen für Wasserbau und Wasserwirtschaft, Rheinish - Westfälische Technische Hochschule Aachen.

ROUVË G., DFG DEUTSCHE FORSCHUNGSGEMEINSCHAFT 1987: Hydraulische Probleme beim naturnahen Gewässerausbau Ergebnisse aus Schwerpunktprogramm "Anthropogene Einflüsse auf hydrologische Prozesse", Band 2.

ŚWIATEK D., KUBRAK J., CHORMAŃSKI J. 2006: Jednowymiarowy model hydrodynamiczny w naturalnych dolinach rzecznych: Na przykładzie Basenu Dolnego rzeki Biebrzy. [Steady $1 \mathrm{D}$ water surface model of natural rivers with vegetated floodplain: An application to the Lower Biebrza]. Proceedings of the International Conference on Fluvial Hydraulics River Flow, Vol. 1, 545-553. 
Streszczenie: Zastosowanie jednowymiarowego modelu hydrodynamicznego do wyznaczania zasięgu zalewu w Basenie Dolnym Biebrzy przy różnym sposobie użytkowania. $\mathrm{W}$ artykule przedstawiono jak różny sposób użytkowania doliny Basenu Dolnego Biebrzy wpływa na zasięg zalewów oraz ich średnią głębokość. Obliczenia przeprowadzono dla przepływu maksymalnego oraz średniej wartości zaobserwowanych przepływów maksymalnych $\mathrm{z}$ wielolecia, obejmującego okres 1965-1996. Obliczone jednowymiarowym modelem hydrodynamicznym rzędne zwierciadła wody wykorzystano za pomocą technik GIS i Numerycznego Modelu Terenu do określenia zasięgu oraz średniej głębokości zalewów. Zastosowany model hydrodynamiczny na podstawie ogólnego prawa przepływu Darcy-Weisbacha oraz procesy wymiany pędu i masy pomiędzy korytem głównym a terenami zalewowymi w ujęciu zaproponowanym przez Pasche, pozwala na uwzględnienie $\mathrm{w}$ obliczeniach wpływu porastają- cej tereny zalewowe roślinności. Cztery scenariusze użytkowania doliny realizowane są $\mathrm{w}$ modelu obliczeniowym poprzez przestrzenną zmienność chropowatości absolutnej roślinności porastającej dolinę rzeki. Scenariusze obejmują działania w zakresie ekstensywnego użytkowania terenów podmokłych, jak koszenie, karczowanie i wypasanie rozległych obszarów łąk. Przeanalizowano również scenariusz, w którym rozległe obszary torfowisk nie są objęte użytkowaniem, lecz są pozostawione do naturalnej sukcesji.

MS. received 7 November 2008

\section{Author's address:}

Katedra Inżynierii Wodnej i Rekultywacji

Środowiska SGGW

ul. Nowoursynowska 166

02-787 Warszawa

Poland 